\title{
Perbedaan Laju Aliran Saliva pada Pengguna Obat Antihipertensi Amlodipin dan Kaptopril di Kelurahan Tumobui Kota Kotamobagu
}

\author{
${ }^{1}$ Febrina G. Wotulo \\ ${ }^{2}$ Pemsi M. Wowor \\ ${ }^{2}$ Aurelia S. R. Supit \\ ${ }^{1}$ Program Studi Pendidikan Dokter Gigi Fakultas Kedokteran \\ ${ }^{2}$ Bagian Farmakologi dan Terapi Fakultas Kedokteran \\ Universitas Sam Ratulangi Manado \\ Email: febrina.wotulo@gmail.com
}

\begin{abstract}
Hypertension is still a major factor of global deaths. There are many antihypertensive drugs inter alia diuretics, beta blockers, angiotensin converting enzyme inhibitors (such as captopril), and calcium antagonists (such as amlodipine). The side effects of the antihypertensive agents amlodipine and captopril in the oral cavity are due to their effects on salivary flow rate which further cause xerostomia. This study was aimed to determine the difference in salivary flow rate between amlodipine consumers and captopril consumers in Tumobui Village Kotamobagu City. This was a descriptive analytical study with a cross sectional design. Subjects were amlodipine consumers and captopril consumers, each of 30 people aged 18-55 years obtained by using purposive sampling technique. Statistical analysis by using the Mann-Whitney $\mathrm{U}$ test showed a $P$ value of $0.932(>0.05)$. Conclusion: There was no significant difference in salivary flow rate between amlodipine consumers and captopril consumers in Tumobui Village Kotamobagu City.
\end{abstract}

Keywords: antihypertensive, amlodipine, captopril, salivary flow rate

\begin{abstract}
Abstrak: Hipertensi merupakan salah satu faktor utama kematian global. Penggunaan obat antihipertensi sangat beragam bagi penyandang hipertensi mulai dari diuretik, penyekat reseptor beta adrenergik, penghambat reseptor angiotensin, penghambat angiotensin converting enzyme (sebagai contoh kaptopril), dan antagonis kalsium (sebagai contoh amlodipin). Amlodipin dan kaptopril menimbulkan efek samping dalam rongga mulut, salah satunya ialah memengaruhi laju aliran saliva yang berlanjut sebagai xerostomia. Penelitian ini bertujuan untuk mengetahui perbedaan laju aliran saliva pada pengguna obat antihipertensi amlodipin dan kaptopril di Kelurahan Tumobui Kota Kotamobagu. Jenis penelitian ialah deskriptif analitik dengan desain potong lintang. Subyek penelitian terdiri dari pengguna obat antihipertensi amlodipin dan pengguna kaptopril masing-masing 30 orang berusia 20-55 tahun, yang diperoleh dengan teknik purposive sampling. Data diperoleh berdasarkan kuesioner penelitian dan pengukuran laju aliran saliva dengan unstimulated salivary flow rate (USFR). Analisis statistik menggunakan uji Mann-Whitney mendapatkan nilai $\mathrm{P}=0,932$ $(>0,05)$. Simpulan: Tidak terdapat perbedaan bermakna antara laju aliran saliva pada pengguna obat antihipertensi amlodipin dan kaptopril di Kelurahan Tumobui Kota Kotamobagu.
\end{abstract}

Kata kunci: antihipertensi, amlodipin, kaptopril, laju aliran saliva

Hipertensi merupakan salah satu faktor risiko utama kematian global. Seseorang dikatakan hipertensi jika tekanan darah sistoliknya lebih tinggi atau sama dengan $140 \mathrm{~mm} \mathrm{Hg}$ serta tekanan darah diastoliknya lebih tinggi atau sama dengan 90 
$\mathrm{mm} \mathrm{Hg}$ atau ketika seseorang sedang mengonsumsi obat antihipertensi untuk mengontrol tekanan darah. ${ }^{1}$

Data World Health Organization (WHO) tahun 2014 menunjukan bahwa prevalensi keseluruhan peningkatan tekanan darah pada orang dewasa berusia lebih dari 18 tahun ialah sekitar $22 \% .{ }^{1}$ Prevalensi hipertensi di Indonesia tahun 2013 sebesar $25,8 \%$ yang didapat melalui pengukuran tekanan darah pada orang berusia lebih dari 18 tahun. $^{2}$ Prevalensi hipertensi di Sulawesi Utara berdasarkan hasil Riset Kesehatan Dasar (Riskesdas) pada tahun 2013 sebesar $27,1 \%{ }^{2,3}$ Walaupun terlihat adanya penurunan prevalensi dibanding tahun 2007 sebesar $31,2 \%$ namun tetap saja hipertensi merupakan salah satu masalah kesehatan yang serius. ${ }^{3}$ Penurunan ini juga terlihat di Kotamobagu yang mengalami penurunan angka kejadian hipertensi sebanyak 8.234 kasus menjadi 6.591 kasus pada tahun 2013. ${ }^{4}$

Berbagai pengobatan telah dilakukan untuk mengatasi masalah hipertensi ini, baik pengobatan secara tradisional seperti penggunaan berbagai dedaunan maupun pengobatan secara ilmiah dengan penggunaan obat-obatan. Obat antihipertensi sangat beragam bagi penyandang hipertensi, mulai dari diuretik, penyekat reseptor beta adrenergic ( $\beta$-blockers), penghambat reseptor angiotensin, penghambat angiotensin converting enzyme (ACE inhibitors) seperti kaptopril dan antogonis kalsium (calciumchannel blockers/CCB) seperti amlodipin. ${ }^{5}$ Kaptopril merupakan obat yang digunakan secara luas untuk penanganan hipertensi dan gagal jantung. Begitu juga dengan amlodipin merupakan obat yang digunakan dalam penanganan hipertensi tetapi keduanya termasuk dalam golongan obat yang berbeda. Kedua obat ini memiliki efek samping yang dapat berpengaruh terhadap sistemik maupun rongga mulut seperti laju aliran saliva. ${ }^{6}$

Laju aliran saliva yang terganggu dapat menyebabkan xerostomia atau biasanya dikenal dengan istilah mulut kering. Laju aliran saliva merupakan parameter yang menggambarkan normal, rendah, atau sangat rendahnya aliran saliva yang dinyatakan dalam satuan $\mathrm{ml} /$ menit. Laju aliran saliva yang diukur ialah laju aliran saliva tanpa stimulasi (unstimulated salivary flow rate/USFR) dan laju aliran saliva terstimulasi (stimulated salivary flow rate/SSFR). ${ }^{7}$

\section{METODE PENELITIAN}

Jenis penelitian ini ialah deskriptif analitik dengan desain potong lintang. Penelitian dilakukan di Kelurahan Tumobui Kota Kotamobagu pada bulan April tahun 2018. Populasi penelitian ialah masyarakat pengguna obat antihipertensi amlodipin dan kaptopril.

Pengambilan sampel menggunakan metode purposive sampling yang memenuhi kriteria inklusi (berusia 20-55 tahun, mengonsumsi obat antihipertensi amlodipin atau kaptopril minimal 6 bulan terakhir, tidak mengonsumsi obat anti-depresan, antipsikotropik, benzodiazepine, atropinik, dan antihistamin) dan kriteria eksklusi (mempunyai penyakit sistemik, menopause, ibu hamil, perokok, pengonsumsi alkohol, puasa, dan tidak kooperatif) dengan jumlah sampel masing-masing 30 orang.

Pengumpulan data dilakukan dengan mengisi kuesioner data demografi dan pengukuran laju aliran saliva, kemudian hasil dari pengukuran dicatat pada lembar formulir pemeriksaan laju aliran saliva.

Data penelitian ini dianalisis dengan menggunakan uji Shapiro-Wilk untuk uji normalitas dan uji Mann Whitney $U$ untuk mengetahui dan menganalisis perbedaan laju aliran saliva pada pengguna obat antihipertensi amlodipin dan kaptopril di Kelurahan Tumobui Kota Kotamobagu. Data hasil penelitian disajikan dalam bentuk tabel kemudian dideskripsikan berdasarkan distribusi frekuensi dan hasil analisis data.

\section{HASIL PENELITIAN}

Tabel 1 menunjukkan distribusi subyek penelitian berdasarkan jenis kelamin pada pengguna obat antihipertensi amlodipin. Subyek berjenis kelamin perempuan sebanyak $60 \%$, lebih banyak daripada subyek laki-laki $40 \%$. 
Wotulo, Wowor, Supit: Perbedaan laju aliran saliva pada pengguna ...

Tabel 1. Distribusi subyek penelitian berdasarkan jenis kelamin pada pengguna amlodipin

\begin{tabular}{ccc}
\hline Jenis kelamin & Frekuensi & $\mathbf{( \% )}$ \\
\hline Perempuan & 18 & 60 \\
Laki-laki & 12 & 40 \\
Total & 30 & 100 \\
\hline
\end{tabular}

Tabel 2 menunjukkan distribusi subyek berdasarkan jenis kelamin pada pengguna kaptopril. Subyek berjenis kelamin perempuan sebesar $63,3 \%$, lebih banyak dari subyek laki-laki yaitu sebesar $36,7 \%$.

Tabel 3 memaparkan distribusi usia subyek penelitian. Subyek terbanyak berusia 41-45 tahun, diikuti usia 36-40 tahun untuk kedua kelompok obat.

Tabel 2. Distribusi subyek penelitian berdasarkan jenis kelamin pada pengguna kaptopril

\begin{tabular}{ccc}
\hline Jenis kelamin & Frekuensi & $\mathbf{( \% )}$ \\
\hline Perempuan & 18 & 60 \\
Laki-laki & 12 & 40 \\
Total & 30 & 100 \\
\hline
\end{tabular}

Tabel 4 memaparkan bahwa lama menyandang hipertensi pada kedua kelompok yang terbanyak ialah 1-5 tahun, diikuti 6-10 tahun. Demikian pula lama penggunaan obat antihipertensi pada kedua kelompok yang terbanyak ialah 1-5 tahun (Tabel 5).

Tabel 3. Distribusi subyek penelitian berdasarkan usia (tahun)

\begin{tabular}{ccccc}
\hline \multirow{2}{*}{ Usia (tahun) } & \multicolumn{2}{c}{ Pengguna amlodipin } & \multicolumn{2}{c}{ Pengguna kaptopril } \\
\cline { 2 - 5 } & $\mathrm{n}$ & $\%$ & $\mathrm{n}$ & $\%$ \\
\hline $20-25$ & 3 & 10 & 1 & 3,3 \\
$26-30$ & 2 & 6,67 & 2 & 6,67 \\
$31-35$ & 5 & 16,7 & 5 & 16,7 \\
$36-40$ & 6 & 20 & 7 & 23,33 \\
$41-45$ & 7 & 23,33 & 8 & 26,7 \\
$46-50$ & 6 & 20 & 6 & 20 \\
$51-55$ & 1 & 3,3 & 1 & 3,3 \\
Total & 30 & 100 & 30 & 100 \\
\hline
\end{tabular}

Tabel 4. Distribusi responden berdasarkan lama hipertensi.

\begin{tabular}{ccccc}
\hline $\begin{array}{c}\text { Lama hipertensi } \\
\text { (tahun) }\end{array}$ & \multicolumn{2}{c}{ Pengguna amlodipin } & \multicolumn{2}{c}{ Pengguna kaptopril } \\
\cline { 2 - 5 } & $\mathrm{n}$ & $\%$ & $\mathrm{n}$ & $\%$ \\
\hline $1-5$ & 17 & 56,7 & 14 & 46,7 \\
$6-10$ & 6 & 20 & 6 & 20 \\
$11-15$ & 4 & 13,3 & 3 & 10 \\
$16-20$ & 3 & 10 & 3 & 10 \\
$21-25$ & 0 & 0 & 1 & 3,3 \\
$26-30$ & 0 & 0 & 2 & 6,7 \\
$31-35$ & 0 & 0 & 1 & 3,3 \\
Total & 30 & 100 & 30 & 100 \\
\hline
\end{tabular}

Tabel 5. Distribusi responden berdasarkan lama penggunaan obat.

\begin{tabular}{ccccc}
\hline \multirow{2}{*}{$\begin{array}{c}\text { Lama penggunaan obat } \\
\text { (tahun) }\end{array}$} & \multicolumn{2}{c}{$\begin{array}{c}\text { Obat antihipertensi } \\
\text { amlodipin }\end{array}$} & \multicolumn{2}{c}{$\begin{array}{c}\text { Obat antihipertensi } \\
\text { kaptopril }\end{array}$} \\
\cline { 2 - 5 } & $\mathrm{n}$ & $\%$ & $\mathrm{n}$ & $\%$ \\
\hline $1-5$ & 26 & 86,7 & 25 & 83,3 \\
$6-10$ & 3 & 10 & 5 & 16,7 \\
$11-15$ & 1 & 3,3 & 0 & 0 \\
Total & 30 & 100 & 30 & 100 \\
\hline
\end{tabular}


Tabel 6 menampilkan bahwa rerata laju aliran saliva pada kedua kelompok pengguna obat antihipertensi yang terbanyak ialah tergolong sangat rendah.

Hasil analisis perbedaan laju aliran saliva pada kedua kelompok pengguna obat antihipertensi amlodipin dan kaptopril mendapatkan signifikansi sebesar 0,932 $(>0,05)$ yang menunjukkan tidak terdapat perbedaan bermakna antara kedua kelompok tersebut.

Tabel 6. Hasil rerata laju aliran saliva pada pengguna obat antihipertensi amlodipin dan kaptopril

\begin{tabular}{ccccc}
\hline \multirow{2}{*}{ Hasil } & \multicolumn{2}{c}{$\begin{array}{c}\text { Obat antihipertensi } \\
\text { amlodipin }\end{array}$} & \multicolumn{2}{c}{$\begin{array}{c}\text { Obat antihipertensi } \\
\text { kaptopril }\end{array}$} \\
\cline { 2 - 5 } & $\mathrm{n}$ & $\%$ & $\mathrm{n}$ & $\%$ \\
\hline Normal & 0 & 0 & 0 & 0 \\
Rendah & 2 & 6,67 & 5 & 16,67 \\
Sangat rendah & 28 & 93,33 & 25 & 83,33 \\
Total & 30 & 100 & 30 & 100 \\
\hline
\end{tabular}

Tabel 7. Hasil analisis perbedaan laju aliran saliva pada pengguna obat antihipertensi amlodipin dan kaptopril

\begin{tabular}{cccc}
\hline $\begin{array}{c}\text { Pengguna obat } \\
\text { antihipertensi }\end{array}$ & n & Mean & Sig. \\
\hline $\begin{array}{c}\text { Amlodipin } \\
\text { Kaptopril }\end{array}$ & 30 & 30,32 & 0,932 \\
\hline
\end{tabular}

\section{BAHASAN}

Obat antihipertensi mempunyai efek samping yang harus dihadapi oleh pengguna obat antihipertensi. Keluhan rongga mulut merupakan salah satu efek samping yang sering ditemukan pada pasien hipertensi. Berdasarkan kelompok usia, laju aliran saliva sangat rendah paling banyak terjadi pada usia 51-55 tahun dengan rerata laju aliran saliva 0,05 $\mathrm{ml} / \mathrm{menit}$. Hal ini sesuai dengan acuan pustaka yang menyatakan bahwa dengan meningkatnya usia, terjadi proses aging yang akan mengakibatkan perubahan dan kemunduran fungsi kelenjar saliva. Parenkim kelenjar hilang dan digantikan oleh jaringan lemak dan penyambung sehingga jumlah aliran saliva berkurang. ${ }^{8}$ Selain itu, faktor hormonal seperti menopause dan kehamilan, perokok, pengonsumsi alkohol dan penggunaan obat antihipertensi juga berpengaruh terhadap terjadinya penurunan laju aliran saliva.

Lama penggunaan obat sangat memengaruhi penurunan laju aliran saliva disebabkan oleh farmakodinamik obat yang menyebabkan penurunan frekuensi denyut jantung dan kontraktilitas miokard, sehinga curah jantung menurun dan volume plasma juga berkurang, sehingga terjadi penurunan laju aliran saliva. ${ }^{9}$

Amlodipin merupakan golongan obat antihipertensi CCB yang bekerja dengan cara menghambat influks kalsium pada otot polos pembuluh darah dan miokard. Kalsium merupakan unsur organik saliva. Bila influks kalsium pada otot pembuluh darah dihambat maka secara tidak langsung akan memengaruhi saliva dengan mengubah keseimbangan cairan dan elektrolit atau dengan memengaruhi aliran darah ke kelenjar. $^{10}$

Kaptopril sebagai obat antihipertensi golongan penghambat ACE (ACE inhibitor) menunjukkan adanya penurunan laju aliran saliva. ${ }^{9,11}$ Cara kerja obat ini dengan menghambat kerja ACE sehingga pembentukan angiotensin II terhambat, terjadi vasodilatasi dan penurunan sekresi aldoteron sehingga ginjal menyekresi natrium, cairan dan kalium. Obat ini secara tidak langsung akan memengaruhi saliva dengan mengubah keseimbangan cairan dan elektrolit. ${ }^{10}$ 
Secara keseluruhan, dari hasil penelitian yang telah dilakukan dapat dinyatakan bahwa penggunaan obat antihipertensi amlodipin dan kaptopril dapat menimbulkan dampak pada rongga mulut berupa penurunan laju aliran saliva secara langsung maupun tidak langsung yang dapat menyebabkan xerostomia. Obat antihipertensi amlodipin dan kaptopril mempunyai fungsi sama tetapi dengan mekanisme kerja yang berbeda dan keduanya menyebabkan pengguna mengalami penurunan laju aliran saliva.

\section{SIMPULAN}

Dari hasil penelitian di Kelurahan Tumobui Kota Kotamobagu dapat disimpulkan bahwa laju aliran saliva pada pengguna obat antihipertensi amlodipin dan kaptopril paling banyak dalam kategori sangat rendah $(>0,1 \mathrm{ml} /$ menit $)$ tetapi tidak terdapat perbedaan bermakna antara laju aliran saliva pada pengguna amlodipin dan kaptopril.

\section{SARAN}

Bagi masyarakat terutama penyandang hipertensi yang mengonsumsi obat antihipertensi amlodipin dan kaptopril untuk menjaga kelembaban rongga mulut dengan rajin meminum air.

Bagi praktisi kesehatan diharapkan agar dapat meningkatkan pelayanan kesehatan gigi dan mulut serta memberi sosialisasi mengenai efek samping dan penanganan dari penggunaan obat antihipertensi.

\section{DAFTAR PUSTAKA}

1. World Health Organization. Global NCD target reduce high blood pressure. WHO. 2016 Sept; p. 1-2.

2. Laporan Riset Kesehatan Dasar (Riskesdas). Jakarta: Departemen Kesehatan Republik Indonesia, 2013; p. 88-90,
3. Laporan Riset Kesehatan Dasar (Riskesdas) Provinsi Sulawesi Utara. Jakarta: Departemen Kesehatan Republik Indonesia, 2007; p. 76.

4. Dukomalamo AM, Pangemanan JM. Hubungan pengetahuan tentang hipertensi dengan komplikasi pada lansia yang berobat di Puskesmas Motoboi Kecil Kecamatan Kotamobagu Selatan. Jurnal Kedokteran Komunitas dan Tropik. 2016;4(1):9-14.

5. Gormer B. Farmakologi Hipertensi. Lyrawati D, penerjemah. 2008; p. 1-8. Available from: https://lyrawati.files. wordpress. com/2008/11/hypertensionhosppharm.p df.

6. Tambuwun PGJ. Gambaran keluhan di rongga mulut pada pengguna obat antihipertensi di Poliklinik Penyakit Dalam Rumah Sakit Tingkat III Robert Wolter Monginsidi Manado. eG. 2015;3(2):241-4.

7. Humphery SP, Williamson RT. A review of saliva: Normal composition, flow, and function. Lexington: Collage of Dentistry, University of Kentucky, 2010; 85(2):162-7

8. Alamsyah RM, Nagara CC. Xerostomia Pada Pasien Hipertensi di Puskesmas Sering dan Sentosa Baru Medan. Universitas Sumatera Utara Medan. Jurnal PDGI. 2015;64(2):110-4.

9. Marlisa. Hubungan obat-obatan antihiper-tensi terhadap terjadinya xerostomia [Skripsi]. Medan: Universitas Sumatera Utara; 2010.

10. Nafrialdi. Antihipertensi. In: Gunawan SG, Setiabudy, R, Nafrialdi, Elysabeth. Farmakologi dan Terapi (5th ed). Jakarta: Departemen Farmakologi dan Terapeutik Fakultas Kedokteran Universitas Indonesia, 2007; p. 341-60.

11. Amalia ZS, Restadiamawati. Pengaruh pengguna kaptopril pada penderita hipertensi terhadap laju aliran saliva dan pembesaran gingiva. Media Medika Muda. 2015;4(4):1-9. 